\title{
Agricultural Practices and Traditional Preservation of Taro (Colocasia spp.) in Abaya Woreda, Southern Ethiopia
}

\author{
Itefa Degefa* and Baressa Anbessa \\ Department of Biology, Bule Hora University, Ethiopia
}

Submission: November 08, 2017; Published: December 20, 2017

*Corresponding author: Itefa Degefa, Faculty of Natural sciences, Department of Biology, Genetics program, Bule Hora University, Ethiopia; Tel: +251917135801, Email: ittafaadaggafaa@gmail.com

Abstract

Background: Taro has been cultivated mainly and extensively in dense populated areas of South, Southwest and Western parts of Ethiopia. It has been used as a food source which minimizes food gaps when other crops are not on the field. The present study was carried out in Abaya Woreda to assess agricultural practices and traditional preservation of taro (Colocasia spp.).

Materials and methods: Data was collected by cluster analysis survey methods from purposively selected three kebeles such as Bochessa, Kalaltu and Guangua Badiya, based up on the cultivation practice of taro and twenty house hold farmers were selected from each kebele by the guidance of DA (Developmental Agencies).

Results: The agronomic practices of these crops shows that there where variation between the kebeles. Godare Gurati is highly cultivated in Bochessa kebele (58.3\%) and in Guangua Badiya (41.7\%). Godare Duri (66.7\%) and Yitri Filatama (85.7\%) are highly cultivated by the farmers of Kalaltu kebele. Taro is propagated highly both by old and young corm in Bochessa kebele as $71.4 \%$ of farmers responded. Farmers of Kalaltu kebele propagate taro crops mostly by young corms (50\%) but very low in Bochessa kebele (10\%). Farmers in Bochessa kebele (61.1\%) practiced both mono-cropping and inter cropping systems. Intercropping system is much known in Kalaltu kebele (73.7\%) and mono-cropping system (52.2\%) of taro crops is highly known than the other kebeles. Seventy five percent of the farmers in Kalaltu kebele plant taro crops randomly without taking care for distance.

Conclusion: As result shows people of the study area have traditional agronomic practices. However there were no any scientific guidance, all farmers are practicing a traditional cultivation way which needs important attention to increase modern cultivation practices for improvement of yield and crops management system

Keywords: Taro; Tradition; Preservation; Agronomy; Practice; Farmers; Colocasia; Knowledge

\section{Introduction}

Taro is one of the world's oldest food crops, dating back over 9,000 years. This ancient crop, first domesticated in Southeast Asia, has continued to spread throughout the world and is now an important crop in Asia, Pacific, Africa and the Caribbean [1]. It is a tropical plant grown primarily for its edible corms. It is very variable robust herb, with leaves up to $2 \mathrm{~m}$ tall. Its leaves peltate and petiole stout is over $1 \mathrm{~m}$ long. It cultivated or naturalized near streams or water falls $500-2000 \mathrm{~m}$. It is cultivated in wet places for its starch rich tubers, which are in South-East Asia or on the Hawaiian Islands [2].

The term taro is frequently used for four aroid species (Alocasiamacrorrhiza L.), Colocasia esculenta (true orordinary taro), Cyrtospermamerkusii and Xanthosomasagittifolium L.).
For agriculture and human consumption, the more important aroid species is Colocasia esculenta. This species is polymorphic and involves two botanical varieties: Colocasia esculenta var. esculenta and Colocasia esculenta var. antiquorum [3]. In Ethiopia, food insecurity is increasing with $55 \%$ of farmers reporting that their annual harvest is insufficient to maintain the family for more than six months. At least seven million people require food aid every year since efforts to address the problem through a grain led approaches has failed even to keep up with population increase. Of the different strategies that should be employed to attain national food self-sufficiency and food security, integration of horticultural crops in the food system is rated among the top. Among the potential horticultural crops for further exploitation, 
root and tuber crops are regarded as the most common starchy staples that could provide a low cost energy in the daily diet of the society [4].

Particularly, taro is important for food security. In Ethiopia, it has been cultivated mainly and extensively in dense populated and high rainfall areas of South, Southwest and Western parts of the country. Its use as a potential crop in Ethiopians has been appreciated since 1984 famine [5]. In some areas, it used as fill seasonal food gaps when other crops are not in the field. It also cultivated because of producing reasonable amounts of yield when other crops hardly grow, resistant to disease and pests, ease of ecological adaptation and utilization of different purposes [6].

There is no international center or collection dedicated to taro. That means it has received relatively little attention from the international agricultural research community. Despite this some countries have a tradition of taro to maintain and explore ways to strengthen the in situ conservation of the crop. Taro is embedded in many cultures as a result of its selection for a wide variety of uses. It is often viewed as intrinsic to cultural identity. Seasonal food shortage is amongst the principal problems of farmers in mid-altitude areas of southern Ethiopia. In some of the poorest nations, taro and sweet potato are important part of food security packages [7]. Information on farmers' traditional knowledge on the production systems and preservation of taro was not documented. Still now there was no detail study of taro agricultural practices and traditional preservation in Abaya Woreda where taro is highly diversified. The present study was carried out in Abaya Woreda; Borana Zone, Southern part of Ethiopia where taro cultivation is common. The study was aimed to assess agricultural practices and traditional preservation of taro (Colocasia spp.) in Abaya Woreda.

\section{Significance of the Study}

Some Ethiopian small land holders and low cash crop producers use different methods to scape themselves from food security problems. As Yared et al. [7] said, in some of the poorest nations, taro and sweet potato are important part of food security packages. Here it was assumed this study has significance for the community as well as for other investigators to know about the background how taro (Colocasia spp.) were maintained and preserved for a long time without knowing the scientific agronomic practices of these crops by the people of the study area.

\section{Materials and Methods}

\section{Study area}

The study was conducted in purposively selected three taro growing kebeles of Abaya Woreda such as Guangua Badiya, Kalaltu and Bochessa. Abaya Woreda is located at N06.43520 and E038.25425 with altitude of $1442 \mathrm{~m}$ above sea level. The district is boarded by Nations, Nationalities and Peoples of Southern Ethiopia Regional State in the north and east, Lake Abaya in the west and Gelana district in the south. The livelihood of the people is mostly pastoral and agro-pastoral [8].

\section{Data collection}

Twenty home gardens from each kebele were selected purposively based up on the tarofarming practices with the guidance of the Developmental Agency (DA). Data was collected from all kebele i.e., sixty home gardens through observation, group discussions and interviews according to Dansi et al. $[9,10]$.

\section{Data analysis}

Collected data from the representative kebeles was analyzed by descriptive statistical methods such as frequency and percentages. A software program SPSS (Version 16:00) was used to accomplish the agronomic practices and traditional conservation of taroin the study area.

\section{Results and Discussion}

Sixty farmers of home gardens were interviewed from the three kebeles of Abaya Woreda and responded for questions regarding to agronomic practices and traditional preservation of Colocasia spp. similar to the report of Tewodros [6] by cluster analysis based on qualitative characters indicated the formation of seven clusters and existence of variability, based on their foliar and subterranean traits (Table 1).

Table 1: ANOVA of Some parameters from farmers for agronomic practices and traditional preservation in Abaya Woreda.

\begin{tabular}{|c|c|c|c|c|c|}
\hline & Sum of Squares & Df & Mean Square & Sig. \\
\hline $\begin{array}{c}\text { Propagation methods } \\
\text { of Colocasia }\end{array}$ & Between Groups & 22.657 & 4 & 5.664 & .110 \\
\hline $\begin{array}{c}\text { Distance farmers use } \\
\text { between the crops }\end{array}$ & Within Groups & 6.076 & 4 & .437 & .000 \\
\hline $\begin{array}{c}\text { The depth the } \\
\text { farmers use }\end{array}$ & Within Groups & 28.835 & 55 & .691 & .510 \\
\hline & Within Groups & 31.171 & 4 & .567 & .313 \\
\hline $\begin{array}{c}\text { Types of fertilizer } \\
\text { farmers use }\end{array}$ & Between Groups & 8.999 & 4 & 2.250 & .004 \\
\hline
\end{tabular}


Advances in Biotechnology \& Microbiology

\begin{tabular}{|c|c|c|c|c|c|}
\hline & Within Groups & 28.334 & 55 & .515 & 2.737 \\
\hline Intercropping system & Between Groups & 10.948 & 4 & .539 & .001 \\
\hline & Within Groups & 29.635 & 55 & 2.158 & .557 \\
\hline Plantation season & Between Groups & 8.634 & 55 & 1.307 & .008 \\
\hline & Within Groups & 30.616 & 4 & .027 & .000 \\
\hline Maturation season & Between Groups & 5.230 & 55 & .033 & .526 \\
\hline Digging requirement & Within Groups & 11.354 & 55 & 3.704 & .000 \\
\hline $\begin{array}{c}\text { Harvested plant part } \\
\text { for consumption }\end{array}$ & Between Groups & .107 & 4.826 & 5 & .174 \\
\hline
\end{tabular}

DF: Degree of Freedom; ANOVA: Analysis of Variance; Sig: Significance value at 0.05

\section{Diversities of taro in study area}

The Woreda has diversities of taro where farmers were practicing agricultural cultivation and indirectly preserving the crops diversities. The following Figure 1A \& 1B shows diversities of taro species which farmers of the Abaya Woreda call by their local names. Local people named these as Godare Gurati, Godare Duri, Yitri Duri, Yitri Filatama and Godare Wolayita. Although Yitri Filatama is scientifically Colocasia esculenta(L.) Schott, the others scientific name is not stated in this even if species belongs to Colocasia genus. Godare Gurati is highly cultivated in
Bochessa kebele (58.3\%) and in Guangua Badiya (41.7\%) but not in Kalaltu kebele. Godare Duri (66.7\%) and Yitri Filatama $(85.7 \%)$ are highly cultivated by the farmers of Kalaltu kebele but they were absent in Bochessa kebele. In Bochessa kebele, there were three types of taro species (Godare Duri, Yitri Duri and Godare Wolayita). In Guangua Badiya there were five types of taro species (Godare Duri, Yitri Duri and Godare Wolayita, Yitri Filatama and Godare Gurati) and four types of taro in Kalaltu kebele (Godare Duri, Yitri Duri and Godare Wolayita and Yitri Filatama).

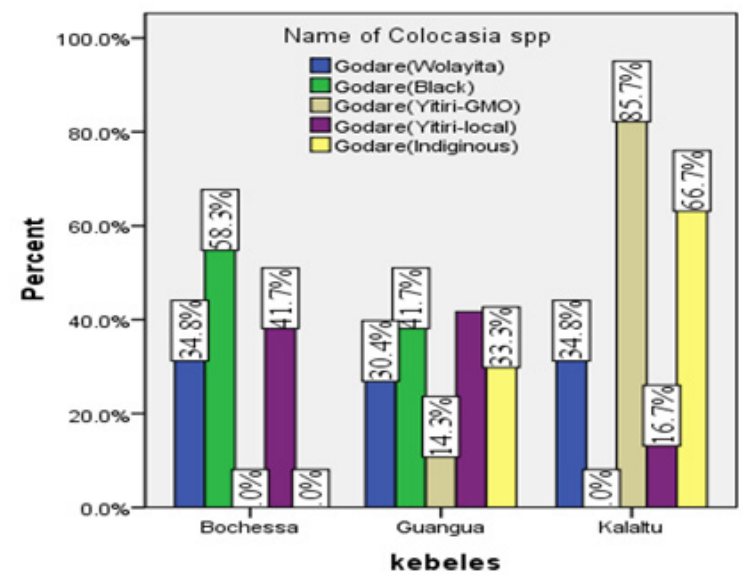

A
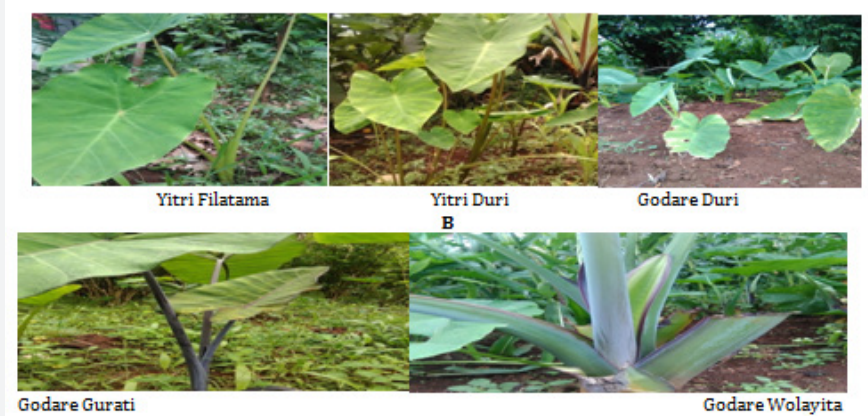

Figure 1: Schematic representation of dimensional changes of polymeric systems upon different stimuli and their resulting response [3]. 
Propagation by both old and young corm is highly practiced by farmers of Bochessa kebele where $71.4 \%$ of them responded but this practice is not known in Guangua Badiya (Figure 2A). Farmers of Kalaltu kebele propagate taro crops mostly by young corms (50\%) but very low in Bochessa kebele (10\%). Taro is propagated by old corms as the farmers in each kebele responded in Bochessa (39.4\%), Guangua Badiya (36.4\%) and
Kalaltu kebele (24.2\%). This study was in line with the study of Yared \& Tewodros [11] who reported as farmers propagate taro vegetatively from the mother plant and the conventional planting materials utilized by farmers at the study sites include corms (13.3\%), cormels (13.3\%), corm pieces $(16.7 \%)$, or combination of corms, cormels and corm pieces (56.7\%).
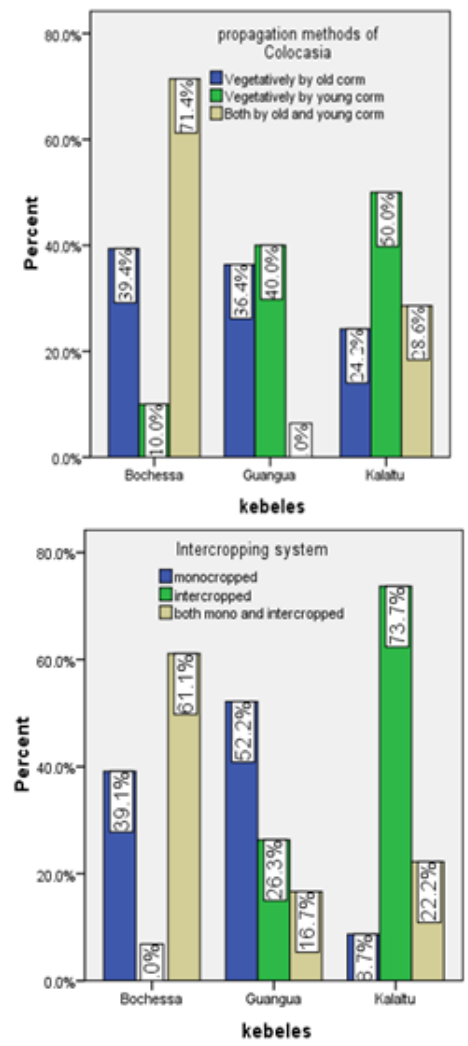

Figure 2A \& 2B: Propagation methods and intercropping systems of Taro cultivated by farmers of Abaya Woreda in percent.

From the following Figure 2B, 61.1\% of farmers in Bochessa kebele practiced both mono-cropping and inter cropping systems of taro crops. $39.1 \%$ of them use mono cropping system. Intercropping system is much known in Kalaltu kebele (73.7\%) than the other kebeles. However, mono-cropping system $(52.2 \%)$ of taro crops is highly known than the other kebeles. This variation may depend up on the indigenous or traditional knowledge the farmers have individually. This result supports the reports of [12]; which says taro was commonly intercropped $20 \%$ with coconut singly or in a mixed cropping system with cocoa, banana, and tamu. It was also a common practice to intercrop taro with banana.

\section{Distances between and within the crops}

Farmers in each kebele used to plant taro with some distances from each other and depth underground according to the following Figure 3A \& 3B. Seventy five percent of the farmers in Kalaltu kebele plant taro crops randomly without taking care for distance. However, 1-1.5m is used between taro crops both by farmers of Bochessa and Kalaltu kebeles (42.1\%). 50cm-
$1 \mathrm{~m}$ distance was highly practiced by the farmers of Guangua Badiya where $45.5 \%$ of them responded (Figure 3A). Using some distance between taro crops is necessary to manage the weed and promotes high yield due to less competition between them for nutrient in the soil in lining with the report of [13] which says taro plant is susceptible to weed competition, especially during the first 3-4 months after planting, and weed control is a beneficial cultural practice at this stage of the growing period. The report of [14] supports this study which says weed control is necessary only during the first three months or so, if crop spacing has been close enough. Thereafter, the crop closes canopy and further weed control is not necessary. Etissa [15] in Belay \& Yared [4] also in line with this result which says the best combination for the highest yield (78.9t/hectare) was obtained from the plant spacing of $30 \mathrm{~cm}$ and row spacing of $70 \mathrm{~cm}$ respectively.

\section{Plantation and maturation season}

Mostly taro is planted in March (71.4\%) and matured in December $(72.7 \%)$ as farmers in Guangua Badiya kebele 
responded in the following Figure $4 \mathrm{~A} \& 4 \mathrm{~B}$. Fifty percent of farmers both in Bochessa and Guangua Badiya kebele responded that as the maturation day of taro crop is in February. Similar to this study, Shifaraw et al. [16] reported the farm operation calendar of some crops in Shishir, land is prepared in December/ autumn and plantation is December to January but harvesting method is determined.
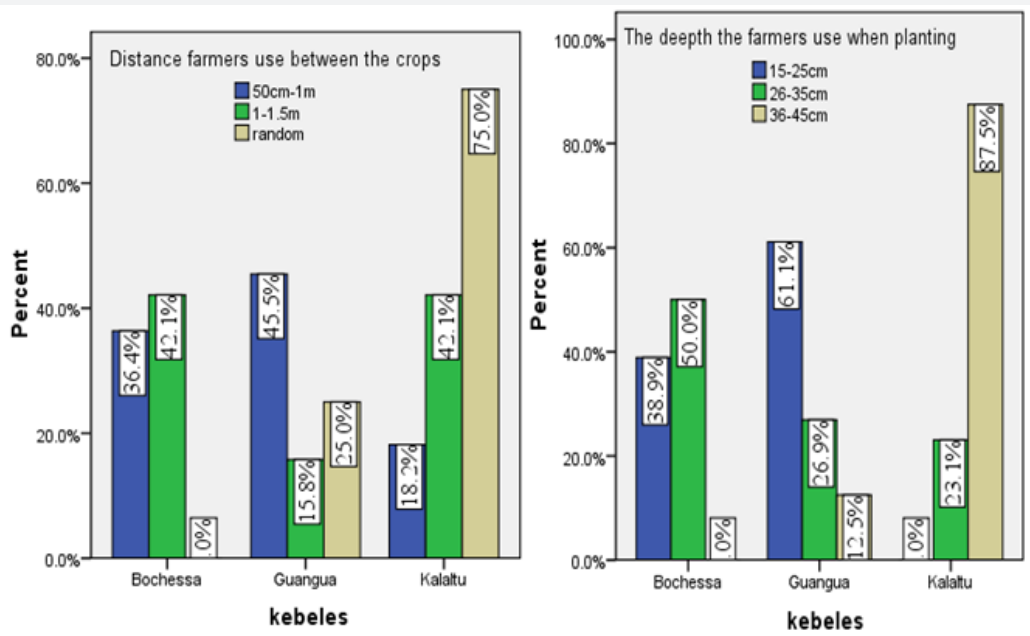

Figure 3A \& 3B: Distance and depth farmer of Abaya Woreda use for taro plantation in percent.
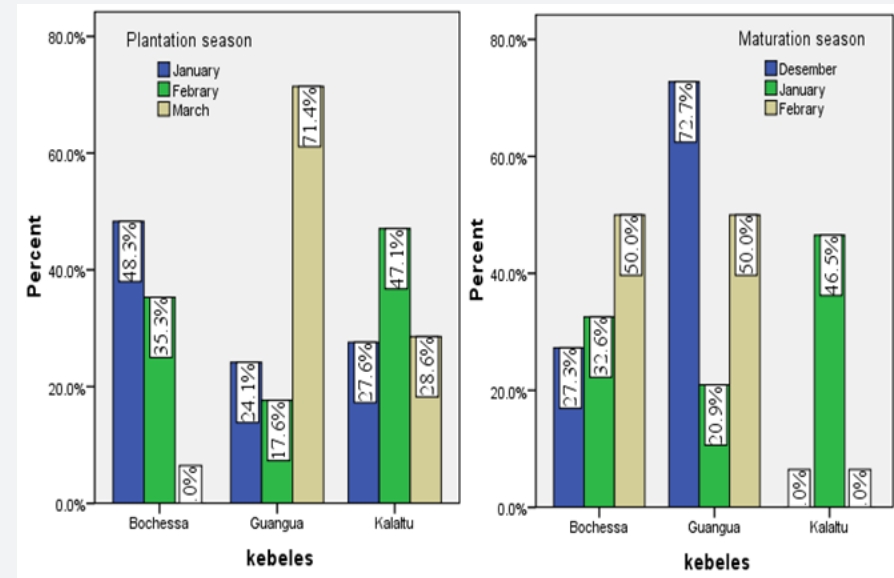

Figure 3A \& 3B: Distance and depth farmer of Abaya Woreda use for taro plantation in percent.
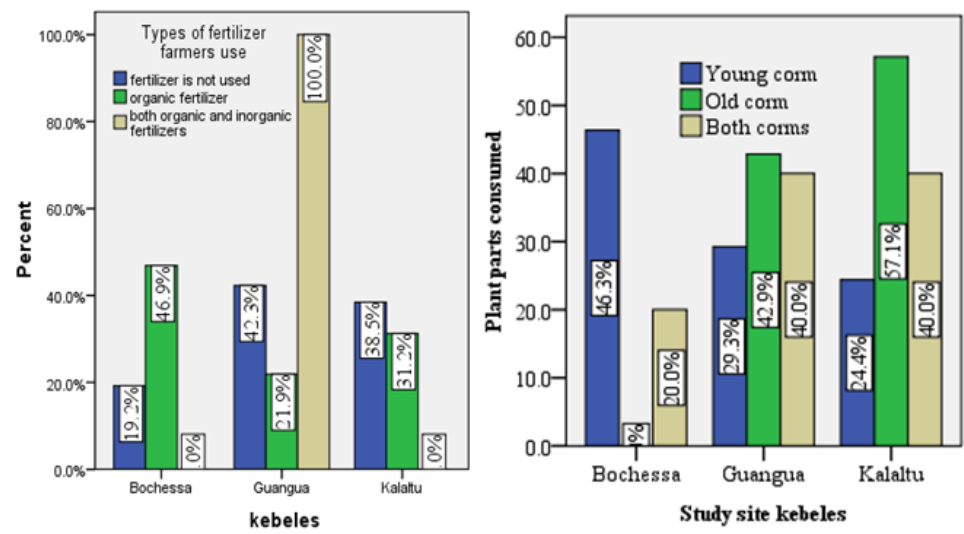

Figure 5A \& 5B: Types of fertilizers and another agronomic practice of farmers to taro in Abaya Woreda. 
Applying both organic and inorganic fertilizers for the taro crops were fully practiced in the Guangua Badiya kebele (100\%) and it was not practiced in Bochessa and Kalaltu accordingly. Planting taro crops without any kind of fertilizer is some time occurred in three kebeles where 19.2\%, 42.9\% and 38.5\% of farmers in Bochessa, Guangua Badiya and Kalaltu kebeles practiced respectively. Organic fertilizer is applied to the soil when planting of taro crops by the farmers of Bochessa (46.9\%), Guangua Badiya (21.9\%) and Kalaltu (31.2\%) kebeles (Figure 5). The result agreed with the report of [11] which says that almost all of the farmers grow taro around homestead as a backyard crop and use organic fertilizers like household refuses/wastes or composts (33.7\%) and manures $(63.3 \%)$ to improve the fertility status of the soil.

Sixty percent of the farmers generally responded that it is important to remove or protect weed from cultivated taro to obtain satisfying yield from the crops. Most of the farmers (96.7\%) responded that as digging is necessary for taro which makes a soil to be soften and smooth for the growing corms of the taro. However, $3.3 \%$ of them said no need to digging and softening of soil (Table 2). This might be due to the type of soil in the study area is totally $(100 \%)$ loam taro can with stand and give yield without digging.

Table 2: General requirement of taro production in Abaya Woreda.

\begin{tabular}{|c|c|c|c|}
\hline & Response & Frequency(N) & Percent (\%) \\
\hline $\begin{array}{c}\text { Types of soils } \\
\text { preferred }\end{array}$ & Loam & 60 & 100.0 \\
\hline & Others & 0 & 0.0 \\
\hline $\begin{array}{c}\text { Weeding } \\
\text { requirement }\end{array}$ & Yes & 60 & 100.0 \\
\hline No & 0 & 0.0 \\
\hline $\begin{array}{c}\text { Digging } \\
\text { requirement }\end{array}$ & Yes & 58 & 96.7 \\
\hline & No & 2 & 3.3 \\
\hline
\end{tabular}

\section{Conclusion}

The study was aimed to assess agricultural practices and traditional preservation of taro (Colocasia spp.) in Abaya Woreda. Based on this objective it can be concluded that farmers of the study area were practice for the cultivation of different crops species where taros diversified differently in the kebeles of study area and main food which they use to fill food gap starting from January at the time of its maturity. They were developed with traditional agronomic practices and they conserve the crops for future use especially, most of the farmers in the Bochessa kebele propagate the crops by both old and young corms more than the kebeles of Guangua Badiya and Kalaltu. Kalaltu keb eleplant the taro crops randomly without determining the distances between crops use ground depth $36-45 \mathrm{~cm}$ during plantation. Using of inorganic fertilizers is not habituated in the area rather they use organic fertilizers mostly the farmers of Bochessa what has to be taken in consideration through advising of the Woreda agricultural office for the farmers to use inorganic fertilizers in order to rise up the yield. Farmers in Bochessa kebele are practicing both of cropping systems since intercropping practices of them was not scientifically as agronomic practices it may cause crops canopy and creates competition for nutrient between them and can minimize the yield at the time of harvesting.

\section{Recommendation}

Here it is important to recommend that diversities of taro in the study area should get attention and it is important to get scientific guidance for the community to strength production, agronomic practices and the traditional preservation should gain attention in collaboration with scientific preservation.

\section{Acknowledgement}

The researcher would like to acknowledge Bule Hora University for its heart fully funding (52,000 Ethiopian Birr) this study. Abaya Woreda administrative and Agricultural office heads as well as DA who were supported us during data collection are highly appreciated.

\section{Contribution of Authors}

Both authors were participated equally in this work especially during data collection, analysis and interpretation of this data to a meaning full paper.

\section{Conflict of Interest}

This manuscript has no conflict in any case and the owner of this manuscript is both Mr. Itefa Degefa and Mr. Baressa Anbessa.

\section{References}

1. Ramanatha V, Rao PJ, Matthews PB, Eyzaguirre, Hunter D (2010) Global diversity of taro; ethnobotany and conservation. Biodiversity International, pp: $1-2$.

2. Edwards S, Demissew S, Hedberg I (1997) Flora of Ethiopia and Eritrea. Hydrocharitaceae to Arecaceae Volume 6. The National Herbarium, Addis Ababa, Ethiopia, and Department of Systematic Botany, Uppsala, Sweden.

3. Ivancic A, Mergedus A, Kristl J, Sober A, Sustar V, etal. (2015) Variation of mineral composition in different parts of taro (Colocasia esculenta) corms. Food Chem 170: 37-46.

4. Belay Y, Yared D (2015) Agronomic research achievements and finding of taro and cassavacrops in Ethiopa: Review. Journal of Agronomy 14(1): 1-5.

5. Amsalu N (2003) Characterization and divergence analysis in cassava (Manihotesculenta Cranz) Genotypes at Jimma. MSc thesis, Alemaya University, Ethiopia.

6. Tewodros M (2011) Exploiting indigenous knowledge for selection and classification of Aerial yam (Dioscorea bulbifera L.) accessions in south and southwestern Ethiopia. Presented the $14^{\text {th }}$ Crop Science Society of Ethiopia, Addis Ababa, Ethiopia, pp. 28-29. 
7. Yared D, Tewodros M, Asfaw K (2014) Development of high yielding taro (Colocasia esculenta L.) variety for mid altitude growing areas of Southern Ethiopia. Journal of Plant Science 2(1): 50-51.

8. Dejene T (2015) Husbandry practices and utilization of camel products in Borana Zone of Southern Oromia, Ethiopia. Science Research 3(4): 191-197.

9. Dansi A, Mignouna HD, Zoundjihékpon J, Sangare A, Ahoussou N et al. (2000) Identification of some Benin Republic's Guinea yams (Dioscorea Cayenensis/Dioscorea Rotundatacomplex) cultivars using randomly amplified polymorphic DNA. Genet Resour Crop Evol 47(6): 619-625.

10. Dansi A, Mignouna HD, Zoundjihékpon J, Sangaré A, Asiedu R, et al. (2000) Using isozyme polymorphism to assess genetic variation within cultivated yams (Dioscorea cayenensis/Dioscorea rotundata complex) of the Republic of Benin. Genet Resour Crop Evol 47: 371-383.

11. Yared D, Tewodros M (2014) Exploring Indigenous knowledge and production constraints of taro (Colocasia esculenta L (SCHOTT)) cultivars grown at dalbo watershed, wolaita zone of South Ethiopia. Greener Journal of Plant Breeding and Crop Science 2(3): 047-053.
12. Liyanage,Ade S, Peni M (1980) Sustainable management practices of taro (Colocasijl Esculenta) production in Western Samoa. Senior Lecturer, University of the South Pacific, and Associate Director (Research), Institute for Research, Extension and Training (IRETA), Alafua Campus, Apia, Western Samoa. ISSN 02719916. No: 044.

13. Purseglove JW (1972) Tropical crops. In: Purseglove JW (Ed.), Monocotyledons. Longman, London, pp. 58-75.

14. Inno 0 (1999) Food and agriculture organizations regional office for Asia and The Pacific Bangkok, Thailand. Taro cultivation in Asia and the Pacific, p. 13.

15. Etissa E (1996) Root and tuber crop crops: Potential as food crops in the humid area of Ethiopia. Newsletter. Agric Res 11: 9-11.

16. Shiferaw T, Dargo F, Osman A (2015) Agropastoralist evaluations of integrated sorghum crop management packages in Eastern Ethiopia. Adv Crop Sci Tech 3: 195.

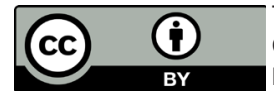

is work is licensed under Creative Commons Attribution 4.0 Licens DOI: 10.19080/AIBM.2017.07.555723

\section{Your next submission with Juniper Publishers will reach you the below assets}

- Quality Editorial service

- Swift Peer Review

- Reprints availability

- E-prints Service

- Manuscript Podcast for convenient understanding

- Global attainment for your research

- Manuscript accessibility in different formats

( Pdf, E-pub, Full Text, Audio)

- Unceasing customer service

Track the below URL for one-step submission https://juniperpublishers.com/online-submission.php 